\title{
Simultaneous Removal of Arsenite and Fluoride from Groundwater using Batch Electrochemical Coagulation Process-Role of Aluminum with Iron Electrodes
}

\author{
SHRUTHI MURTHY ${ }^{1 *}$, MAHESH SHIVASWAMY ${ }^{2}$, SAHANA MAHESH $^{3}$ \\ and SRIKANTHA HANUMANTHAPPA ${ }^{4}$
}

\begin{abstract}
${ }^{1}$ Department of Environmental Engineering, SJCE (JSS S \&T University) Mysuru and Assistant
Environmental Officer, Karnataka State Pollution Control Board, Mysuru, India.

2,3Department of Environmental Engineering, SJCE (JSS S \&T University) Mysuru, India.

${ }^{4}$ Department of Civil Engineerig, School of Engineering \& Technology, Jain University (Deemed-to-be),

JGI Global Campus, Kanakapura Road, Bengaluru Rural, Karnataka, India.

*Corresponding author E-mail: shruthimvj@gmail.com
\end{abstract}

http://dx.doi.org/10.13005/ojc/350110

(Received: August 20, 2018; Accepted: January 14, 2019)

\begin{abstract}
Aluminum(Al) and Iron(Fe) electrodes were used for simultaneous removal of arsenite and fluoride from ground water using novel electrochemical coagulation (ECC)with special focus on electrode placing positions of $\mathrm{Fe}$ and $\mathrm{Al}$ in a batch electrochemical reactor (BECR). A series of experiments were carried out to observe the influence of electrode placing positions on removal. Of the many electrode combination, $\mathrm{Al}_{1}-\mathrm{Al}_{2}-\mathrm{Al}_{3}-\mathrm{Al}_{4}, \mathrm{Fe}_{1}-\mathrm{Fe}_{2}-\mathrm{Fe}_{3}-\mathrm{Fe}_{4}, \mathrm{Al}_{1}-\mathrm{Al}_{2}-\mathrm{Fe}_{3}-\mathrm{Al}_{4}$ and $\mathrm{Fe}_{1}-\mathrm{Fe}_{2}-\mathrm{Al}_{3}-\mathrm{Fe}_{4}$ are discussed in this paper for pre-optimized operating conditions: 4 plate electrodes, $A s(I I I)_{0}: 1.6 \mathrm{mg} / \mathrm{L}, \mathrm{F}_{0}: 12 \mathrm{mg} / \mathrm{L}, \mathrm{A} \mathrm{l}^{3+}: 0$ $\mathrm{mg} / \mathrm{L}, \mathrm{Fe}_{0}: 0.061 \mathrm{mg} / \mathrm{L}$, inter-electrode spacing: $5 \mathrm{~mm}$, applied cell voltage: $16 \mathrm{~V}, \mathrm{SA} / \mathrm{V}$ ratio: $40 \mathrm{~m}^{2} / \mathrm{m}^{3}$ and electrolysis time of 45 minutes. For the said electrode combinations, the maximum simultaneous removal of both arsenite and fluoride was obtained for $\mathrm{Fe}_{1}-\mathrm{Fe}_{2}-\mathrm{Al}_{3}-\mathrm{Fe}_{4}$ with $97 \%$ arsenite removal from its initial value of $1.6 \mathrm{mg} / \mathrm{L}$; and $100 \%$ fluoride removal from its initial value of $12 \mathrm{mg} / \mathrm{L}$ within $45 \mathrm{~min}$ of ET. Energy consumption was $2.01 \mathrm{KWh} / \mathrm{m}^{3}$ with operating cost of $2.90 \mathrm{Rs} . / \mathrm{m}^{3}$.
\end{abstract}

Keywords: Arsenite andfluoride removal, Aluminum, Iron electrodes, Electrode placing position.

\section{INTRODUCTION}

Providing clean and potable water to people is a challenging task. Fresh water contamination is a worldwide health related issue requiring great attention because of its hazardous effects, risks to human health and economic damages ${ }^{1}$ as well. Among the wide variety of contaminants affecting fresh water resources, arsenic and fluoride are important water quality parameters because of its extreme toxicity potential even at low concentrations. Long-term exposure to inorganic arsenic causes many adverse human health effects including cardiovascular, hepatic, and renal diseases in addition to cancer in kidney, liver, lungs, urinary bladder, and skin. Arsenic in drinking water is also

This is an Open Access article licensed under a Creative Commons license: Attribution 4.0 International (CC- BY). Published by Oriental Scientific Publishing Company @ 2018

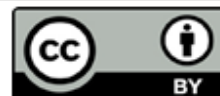


linked to lung cancer and other diseases including peripheral neuropathy, skin lesions, skin cancer and bladder cancer ${ }^{2}$. Table1 shows the health effects from arsenic concentrations in water.

Table 1: Arsenic health effects

\begin{tabular}{lc}
\hline Health Effects & Concentration in water \\
\hline IQ deficit & $10 \mu \mathrm{g} / \mathrm{L}$, children \\
& $11 \mu \mathrm{g} / \mathrm{L}$, children; \\
& $30 \mu \mathrm{g} / \mathrm{L}$, adults \\
Skin Keratosis & $50 \mu \mathrm{g} / \mathrm{L}$ \\
Artery, arteriole and capillary disease & $20-91.5 \mu \mathrm{g} / \mathrm{L}$ \\
Cerebral infarct & $166 \mu \mathrm{g} / \mathrm{L}$ \\
Cerebrovascular disease & $189 \mu \mathrm{g} / \mathrm{L}$ \\
Abnormal electromyograms & $60-140 \mu \mathrm{g} / \mathrm{L}$ \\
Spontaneous abortion and perinatal death & $60-470 \mu \mathrm{g} / \mathrm{L}$ \\
\hline
\end{tabular}

Similarly, the detrimental effects of long-term ingestion or exposure to high concentrations of fluoride in drinking water are known for physiological disorders, dental and skeletal fluorosis, thyroxine changes, and kidney damage ${ }^{3}$. Table 2 shows different human health effects ranging from $<0.5$ to $>10$ of fluoride in drinking water. The World Health Organization (WHO) sets the maximum contamination level (MCL) for arsenic as $10 \mu \mathrm{g} / \mathrm{L}$. Similarly, the maximum acceptable concentration of fluoride anions in drinking water set by WHO is $1.5 \mathrm{mg} / \mathrm{L}$ at rejection level ${ }^{4}$ and lower values at acceptable levels of $1.0 \mathrm{mg} / \mathrm{L}$; the same values are retained in ${ }^{5}$ (BIS-Bureau of Indian Standards : 10500-91, 2003. India).

Table 2: Health Effects of Fluoride

\begin{tabular}{cc}
\hline $\begin{array}{c}\text { Fluoride value in } \\
\text { water, mg/L }\end{array}$ & Health effects \\
\hline$<0.5$ & Dental caries \\
$0.5-1.5$ & Promotes dental health \\
$1.5-2.5$ & Dental fluorosis \\
$2.5-4$ & Dental fluorosis \\
$>4$ & Dental, skeletal fluorosis \\
$>10$ & Osteosclerosis \\
\hline
\end{tabular}

The increased attention to arsenic and fluoride toxicity on human beings has incited considerable research for developing new robust and reliable methods for removing arsenite and fluoride from ground water. Past treatment processes for arsenic removal were coagulation/filtration ${ }^{6}$, manganese green sand filtration, reverse osmosis, electro dialysis reversal and oxidation/filtration, ion exchange, adsorption using adsorbents such as activated carbon, granular ferric oxides, iron oxide coated sand $d^{7,8}$. The most popular processes for drinking water defluoridation are adsorption using activated alumina ${ }^{9}$ bone char $^{10}$, activated carbon ${ }^{11}$ and coagulation using aluminum salts ${ }^{12}$. Other defluoridation processes include electrodialysis ${ }^{13}$, reverse osmosis ${ }^{14}$ and nanofiltration ${ }^{15}$. These processes show high HRT, expensive set-up, high capital costs, not economically viable for small communities and also no table to treat concentration surges in arsenic and fluoride valuesand also very high maintenance requirements. Moreover, the above treatment methods require a long treatment train with number of unit operations and unit processes with $\mathrm{pH}$ adjustments as well as addition of non-stoichiometric acid andalum coagulants, ferric sulphate/chloride, lime, caustic/polymeric flocculants and follow-up retrofits. Furthermore, these processes defectively generate secondary pollutants like chlorides and sulphate in the coagulation-precipitation process, loaded with unreacted chemicals and large volumes of sludge demanding further treatment and safe disposal of solid residues. In view of the above issues, research intensification for developing an alternate novel treatment processes for simultaneous removal of arsenic and fluoride at low HRT, minimum operation and maintenance costis much needed.

ECC as a novel treatment technology utilizes less current for the dissolution of metal electrodes and higher treatment. Depending on the electrode selected the dissolved $\mathrm{M}^{+}$ions at wide range of $\mathrm{pH}$ forms coagulating species and metals hydroxides. These hydroxides have potential to destabilize even the smallest negatively charged particles which precipitate and adsorb the dissolved contaminants. Finally, precipitate removal by electro-flotation or by sedimentation by bubble-buoyadhesionand transport to the top of the bulk solution for maturation and aggregation, where the sludge gets separated later downline.

Previous researchers have mainly focused on ECC treatment efficiency for either arsenic or fluoride removal in separate studies. In contrast, we investigate to assess the best positions of iron and aluminum electrodes inside the ECC reactor in bipolar arrangement for simultaneous removal of fluoride and arsenic from ground water. The appropriate electrolysis time (ET) required for each combination is based on the stable/matured state of 
the flocs matrix in the reactor and target levels of fluoride and arsenic, energy consumption, electrode dissolution, sludge generation, passivation factor, quality of the ECC treated water and above allthe operating cost.

\section{MATERIALS AND METHODS}

\section{Chemicals and analytical methods}

All the chemicals used in this study were of analytical reagent $(A R)$ grade obtained from $\mathrm{Hi}$ - Media laboratories Pvt. Ltd, Mumbai, India. The analysis of various physico-chemical water quality parameters were carried out using various equipments and instruments. $\mathrm{pH}$ was measured using $\mathrm{pH}$ meter ( $\mathrm{LI}$ 127 Elico make), electrical conductivity using a digital conductivity meter (Systronics model 30/10FT YSI) and temperature variations recorded using a digital thermometer. Iron, nitrate, fluoride, sulphate and phosphate concentrations were determined using UV-spectrophotometer. Total hardness, total alkalinity and TDS was determined as per Standard Methods ${ }^{16}$ (APHA, 2017). Aluminum and arsenic concentrations in the solution were determined using Inductively
Coupled Plasma (ICP Horiba JobinYvon, France).

\section{Characterization of groundwater}

Groundwater samples was collected as and when required from a nearby groundwater source and analyzed for various drinking water quality parameters following the Standard methods (APHA, 2017) and is presented in Table 3. These parameters were analyzed to have clear idea about the chemistry of the water undergoing the ECC process for complete understanding of the interactions that occurin the ECC reactor. Arsenite stock solution of $1000 \mathrm{mg} / \mathrm{L}$ was prepared by dissolving desired amount of sodium meta-arsenite to spikethe sampled groundwater to obtain the desired initial concentration $\left(\mathrm{As}_{0}\right)$ before ECC. Similarly, fluoride stock solution was prepared to get the desired $\mathrm{F}^{-}$concentration as $\mathrm{F}_{0}$ - for experimental use. Arsenite was chosen for ECC treatment because it is 25-60 times more toxic and mobile, in groundwater aquifers whereas, fluoride causes irreversible and health issues. Arsenite and fluoride removal is beena challenging taskin ground reality to make it potable.

Table 3: Initial Characterization of Groundwater before Electrochemical treatment

\begin{tabular}{|c|c|c|c|c|c|}
\hline \multirow[t]{2}{*}{ SI. No. } & \multirow[t]{2}{*}{ Water quality parameter } & \multirow[t]{2}{*}{ Units } & \multirow{2}{*}{$\begin{array}{l}\text { Characterized } \\
\text { values }\end{array}$} & \multicolumn{2}{|c|}{ BIS (IS 10500-91, Revised 2003) } \\
\hline & & & & Desirable limit & Permissible limit \\
\hline 1 & Color & Hazen & Colorless & 5.0 & 25 \\
\hline 2 & Temperature & ${ }^{\circ} \mathrm{C}$ & 22-29 & - & - \\
\hline 3 & $\mathrm{pH}$ & - & $7.52-7.73$ & $6.5-8.5$ & No relaxation \\
\hline 4 & Total Alkalinity as $\mathrm{CaCO}_{3}$ & $\mathrm{mg} / \mathrm{L}$ & $360-377$ & 200 & 600 \\
\hline 5 & Electrical Conductivity & $\mu \mathrm{S} / \mathrm{cm}$ & $807-1075$ & - & - \\
\hline 6 & Turbidity & NTU & $0.29-1$ & 5 & 10 \\
\hline 7 & Chloride & $\mathrm{mg} / \mathrm{L}$ & $70-91$ & 250 & 1000 \\
\hline 8 & Total Hardness asCaCO ${ }_{3}$ & $\mathrm{mg} / \mathrm{L}$ & $352-463$ & 300 & 600 \\
\hline 9 & Calcium Hardness as $\mathrm{CaCO}_{3}$ & $\mathrm{mg} / \mathrm{L}$ & $140-160$ & 75 & 200 \\
\hline 10 & Magnesium Hardness as $\mathrm{CaCO}_{3}$ & $\mathrm{mg} / \mathrm{L}$ & $212-253$ & 30 & 100 \\
\hline 11 & Iron & $\mathrm{mg} / \mathrm{L}$ & $0.01-0.03$ & 0.3 & 1.0 \\
\hline 12 & Fluoride & $\mathrm{mg} / \mathrm{L}$ & $1.08-1.10$ & 1.0 & 1.5 \\
\hline 13 & Arsenic & $\mathrm{mg} / \mathrm{L}$ & Nil & 0.01 & 0.05 \\
\hline 14 & Aluminum & $\mathrm{mg} / \mathrm{L}$ & Nil & 0.03 & 0.2 \\
\hline
\end{tabular}

\section{EXPERIMENTAL}

The laboratory scale batch electrochemical coagulation (BECC) unit was designed and fabricated using organic glass to function as electrochemical reactor (ECR). The experimental set up comprised of an ECC reactor of cubical shape having an effective volume of $2 \mathrm{~L}$ with internal dimensions $12 \mathrm{~cm} \times 11 \mathrm{~cm}$ $x 17 \mathrm{~cm}$. The electrode holding arrangements were made of perspex glasson the inner opposite sides of the walls of the reactor. A larger depth for inductive stirring at the bottom of thevertical electrode plates was provided for achieving effective mixing of the bulk fluid in the ECR. Mixing of bulk solution in ECR was achieved by means of an inductive magnetic stirrer (REMI 2MLH) with rotation speeds optimized at $410 \mathrm{rpm}$. Iron and aluminum sheets of dimensions $10 \mathrm{~cm} \times 10 \mathrm{~cm} \times 0.1 \mathrm{~cm}$ were arranged bipolar in parallel keeping inter-electrode distance of $5 \mathrm{~mm}$. The current input from DC power supply unit was 
maintained constant using a precision DC power supply (Textroni x 35D, Dual regulated powers supply, 0-16V, 0-10A) unit. The DC power supply unit was switched on with apre-optimized cell voltage kept at $16 \mathrm{~V}$ which was obtained as an optimum voltage in preliminary studies. All the batch ECC runs were performedat room temperature.

In each experimental run, $2 \mathrm{~L}$ of arsenite and fluoride spiked groundwater was fed into the reactor. All the BECC experiments were carried out for various electrode placing positions in the ECR (Fig.1(a) and 1(c)). Samples were retrieved at regular time intervals, filtered and analyzed for residual arsenite, fluoride, iron and aluminum concentrations after each ECC run. After ET (electrolysis time), the electrodes were taken out of the ECR, a gentle mixing was attained for treated water using a glass rod so that the flocs again re-flocculateto form larger floc matrix and settle down in the reactor in $<5$ min is shown in Fig. 1 (b) and 1(d). Later, the supernatantwas decanted and filtered for further analysis forthe water quality parameters. The wet solid residue/sludgewas collected in porcelain dishes, dried in a hot air oven at $110^{\circ} \mathrm{C}$. The dried sludge was further subjected to physico-chemical and elemental characterization. At the start and end of each experimental run, the electrodes were washed thoroughly with water followed by $15 \% \mathrm{HCl}$ solution to release entrapped flocs in pits of the electrode faces and again washed with distilled water, dried and weighed. The difference in weight was noted for each electrodes because this information was used to estimate electrode consumption.

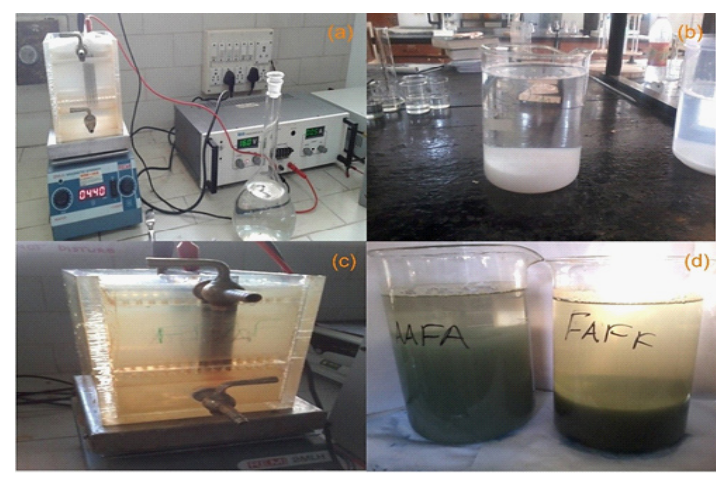

Fig. 1. Experimental set up of Laboratory scale batch electrochemical coagulation unit (a) ECR with aluminum electrodes for As(III) \& F- removal (b) Aluminum hydroxide sludge settled using $\mathrm{Al}_{1}-\mathrm{Al}_{2}-\mathrm{Al}_{3}-\mathrm{Al}_{4}$ at the bottom of the beaker after ECC (c) ECR with iron \& aluminum electrodes for $\mathrm{As}$ (III) \& F- removal (d) $\mathrm{Fe}(\mathrm{OH})_{3}+\mathrm{Al}(\mathrm{OH})_{3}$ sludge using iron and aluminum electrodes

\section{RESULTS AND DISCUSSION}

In any electrochemical treatment process, different electrode materials and compatible electrode combinations are regarded as significant factors influencing the performance of the ECC process ${ }^{17}$. The appropriate selection of the electrode material and its position in the ECR play an important role in delivering the proper $\mathrm{M}^{+}$ions to remove fluoride and arsenite simultaneously from water/ground water.To study the effect of type of electrode (Al and $\mathrm{Fe}$ ) and its positions in the reactor for simultaneous removal of arsenite and fluoride from groundwater a series of 16 sets of experiments were carried out for different electrode bipolar combinations like: (1) $\mathrm{Al}_{1}-\mathrm{Al}_{2}-\mathrm{Al}_{3}-$ $\mathrm{Al}_{4}$,(2) $\mathrm{Al}_{1}-\mathrm{Fe}_{2}-\mathrm{Fe}_{3}-\mathrm{Fe}_{4}$ (3) $\mathrm{Al}_{1}-\mathrm{Fe}_{2}-\mathrm{Fe}_{3}-\mathrm{Al}_{4}(4) \mathrm{Al}_{1}-\mathrm{Al}_{2}-$ $\mathrm{Fe}_{3}-\mathrm{Al}_{4}(5) \mathrm{Al}_{1}-\mathrm{Al}_{2}-\mathrm{Al}_{3}-\mathrm{Fe}_{4}(6) \mathrm{Al}_{1}-\mathrm{Fe}_{2}-\mathrm{Al}_{3}-\mathrm{Fe}_{4}(7) \mathrm{Al}_{1}-$ $\mathrm{Al}_{2}-\mathrm{Fe}_{3}-\mathrm{Fe}_{4}(8) \mathrm{Al}_{1}-\mathrm{Fe}_{2}-\mathrm{Al}_{3}-\mathrm{Al}_{4}(9) \mathrm{Fe}_{1}-\mathrm{Fe}_{2}-\mathrm{Fe}_{3}-\mathrm{Fe}_{4}(10)$ $\mathrm{Fe}_{1}-\mathrm{Fe}_{2}-\mathrm{Al}_{3}-\mathrm{Al}_{4}(11) \mathrm{Fe}_{1}-\mathrm{Al}_{2}-\mathrm{Al}_{3}-\mathrm{Al}_{4}(12) \mathrm{Fe}_{1}-\mathrm{Al}_{2}-\mathrm{Al}_{3}-\mathrm{Fe}_{4}$ (13) $\mathrm{Fe}_{1}-\mathrm{Fe}_{2}-\mathrm{Fe}_{3}-\mathrm{Al}(14) \mathrm{Fe}_{1}-\mathrm{Fe}_{2}-\mathrm{Al}_{3}-\mathrm{Fe}_{4}(15) \mathrm{Fe}_{1}-\mathrm{Al}_{2}-$ $\mathrm{Fe}_{3}-\mathrm{Fe}_{4}$ and (16) $\mathrm{Fe}_{1}-\mathrm{Al}_{2}-\mathrm{Fe}_{3}-\mathrm{Al}_{4}$.

Out of the above said 16 sets of bipolar electrode arrangements, the results of only four sets of experiments are presented for discussion because other electrode arrangements showed poor As and $\mathrm{F}$ - removal and also other removal of water quality parameters. The four electrode arrangements discussed are: (1) 4 aluminum electrodes $\left(\mathrm{Al}_{1}-\mathrm{Al}_{2}\right.$ $\left.\mathrm{Al}_{3}-\mathrm{Al}_{4}\right),(2) 4$ iron electrodes $\left(\mathrm{Fe}_{1}-\mathrm{Fe}_{2}-\mathrm{Fe}_{3}-\mathrm{Fe}_{4}\right)$ (3) 3 Aluminum electrodes and 1 iron electrode $\left(\mathrm{Al}_{1}-\mathrm{Al}_{2}-\right.$ $\mathrm{Fe}_{3}-\mathrm{Al}_{4}$ ), and (4) 3 iron electrodes and 1 aluminum electrode $\left(\mathrm{Fe}_{1}-\mathrm{Fe}_{2}-\mathrm{Al}_{3}-\mathrm{Fe}_{4}\right)$. Fig. $2(\mathrm{a}-\mathrm{d})$ shows these four different electrode configurations in bipolar arrangement with electrodes placed in parallel.

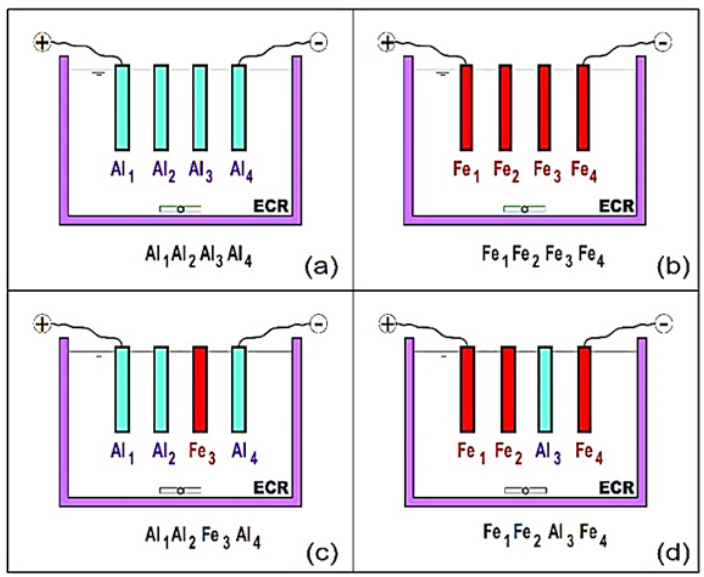

Fig. 2. Schematic diagram showing electrode (Fe and $\mathrm{Al}$ ) placing positions (bipolar mode) in the ECR 
Effect of using 4 aluminum (4AI) electrodes for simultaneous removal of arsenite and fluoride

Batch ECC experiments were carried out using four Al plate electrodes arranged in parallel having SA/Vof $40 \mathrm{~m}^{2} / \mathrm{m}^{3}$. With a bipolar connection, the electrode arrangement was: $\mathrm{Al}_{1}-\mathrm{Al}_{2}-\mathrm{Al}_{3}-\mathrm{Al}_{4}$; at an inter-electrode spacing of $5 \mathrm{~mm}$ operated at a cell voltage of $16 \mathrm{~V}$ and a corresponding current of $0.61 \mathrm{~A}$ for $45 \mathrm{~min} \mathrm{ET}$ with background $\mathrm{Fe}$ and $\mathrm{Al}$ concentrations in groundwater was $0.061 \mathrm{mg} / \mathrm{L}$ and $0 \mathrm{mg} / \mathrm{L}$ respectively with initial $\mathrm{pH}_{0}$ of 8.9 .
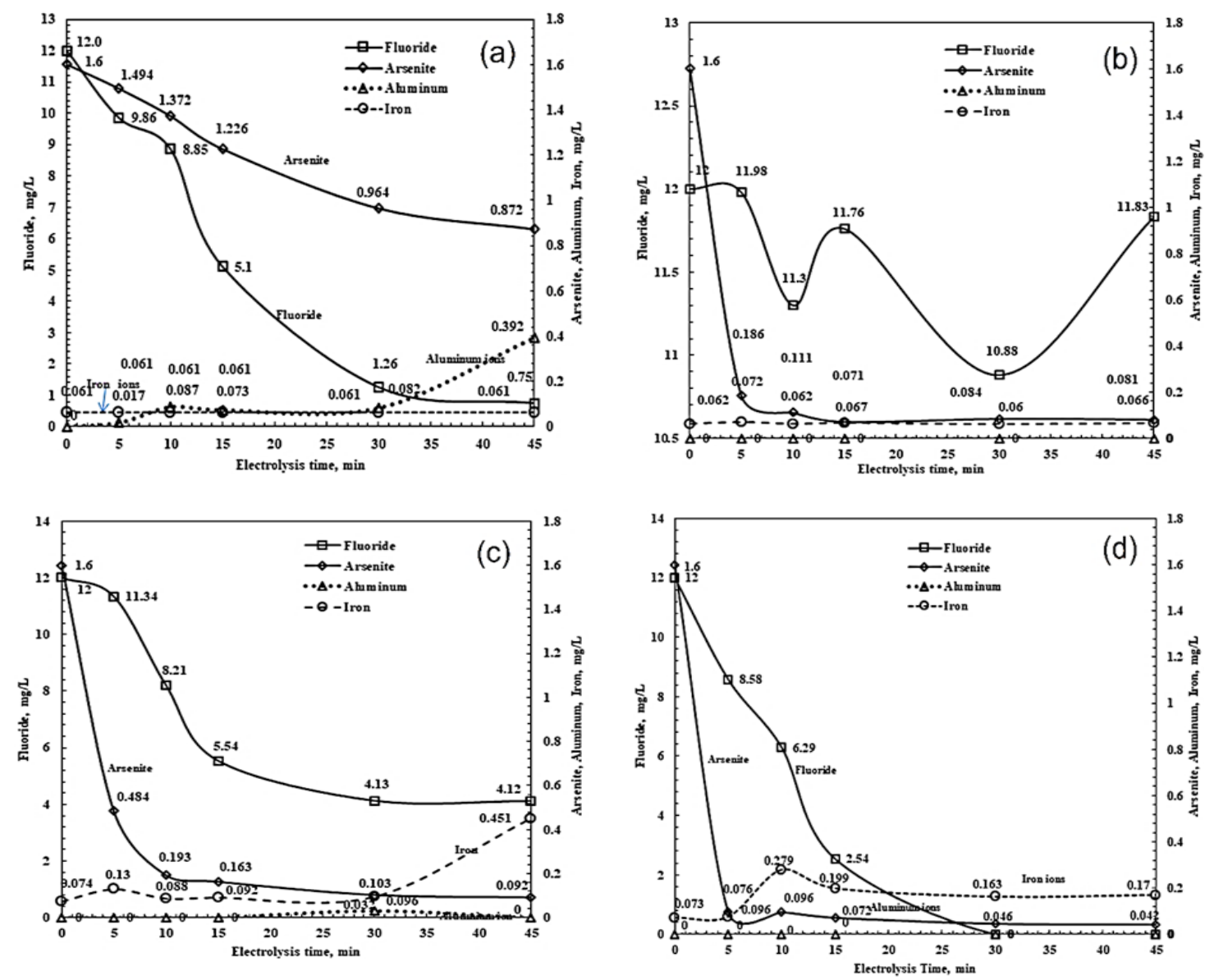

Fig. 3. (a)Variations in fluoride and arsenite concentrations during batch ECC using 4 aluminum electrodes. (b) Variations in fluoride and arsenite concentrations during batch ECC using 4 iron electrodes. (c) Variations in fluoride and arsenite concentrations during Batch ECC using $3 \mathrm{Al}+1 \mathrm{Fe}$ Electrodes. (d) Variations in fluoride and arsenite concentrations during batch ECC using 3Fe+1Al Electrodes

Figure 3(a) shows the reduction in fluoride and arsenite concentration with time during the ECC process. Fluoride concentrations reduce significantly compared to arsenite in the bulk solution. Fluoride concentrations reduced to $<0.3 \mathrm{mg} / \mathrm{L}$ from its $\mathrm{C}_{0}$ value of $12 \mathrm{mg} / \mathrm{L}$. During the first $5 \mathrm{~min}$ of $\mathrm{ET}, \mathrm{Al}^{3+}$ ions released from the anode making the bulk solution turbid with $9.86 \mathrm{mg} / \mathrm{L}$ of fluoride remaining in solution;at this time Al concentration in the bulk solution was $0.017 \mathrm{mg} / \mathrm{L}$ proving the liberation of $\mathrm{Al}^{3+}$ as charged in-situ coagulants required for floc formation in the presence of sufficient alkalinity ranging from $360-377 \mathrm{mg} / \mathrm{L}$. During this time, a slight increase in the bulk solution temperature occurs. As a result of exothermic reactions, the hydrated trivalent aluminum ion under goes hydrolysis generating various monomeric, dimeric, trimeric and polynuclear hydrolysis products as shown through equations (1)-(3) by ${ }^{18}$.

$\mathrm{Al}^{3+}+\mathrm{H}_{2} \mathrm{O} \rightarrow \mathrm{Al}(\mathrm{OH})^{2+}+\mathrm{H}^{+}$

$\mathrm{Al}(\mathrm{OH})^{2+}+\mathrm{H}_{2} \mathrm{O} \rightarrow \mathrm{Al}(\mathrm{OH})_{2}{ }^{+}+\mathrm{H}^{+}$

$\mathrm{Al}(\mathrm{OH})^{2+}+\mathrm{H}_{2} \mathrm{O} \rightarrow \mathrm{Al}(\mathrm{OH})_{3}+\mathrm{H}^{+}$ 
These $\mathrm{H}^{+}$ions make water near the anode slightly acidic and because of continuous inductive stirring, slowly the $\mathrm{pH}$ of the bulk solution drops down from 8.9 to 7.8 at $30 \mathrm{~min}$ ET with a fluoride reduction of $90 \%\left(\mathrm{~F}_{0}: 12 \mathrm{mg} / \mathrm{L}, \mathrm{F}_{0}: 1.26 \mathrm{mg} / \mathrm{L}\right)$ following the reaction shown in equation(4).

$\mathrm{Al}(\mathrm{OH})^{3+} \mathrm{xF}^{-} \rightarrow \mathrm{Al}(\mathrm{OH})_{3-\mathrm{x}} \mathrm{F}_{\mathrm{x}}+\mathrm{xOH}^{-}$

The fluoride ions exchanges partially with $\mathrm{OH}$ - ions in the $\mathrm{Al}(\mathrm{OH})_{3}$ matrix to free the $\mathrm{OH}$ causing a slight increase in $\mathrm{pH}$ from 7.8 to 8.1 at $45^{\text {th }}$ min of ET. Arsenite showed a meager $55 \%$ removal at $45 \mathrm{~min}$ ET from its initial concentration of $1.6 \mathrm{mg} / \mathrm{L}$; this level of removal is assumed to have occurred because of the background iron concentration in the bulk solution. $\mathrm{Al}^{3+}$ ions showed unsatisfactory results on arsenite removal compared to the removal of fluoride. The moment fluoride values reduced to $1.26 \mathrm{mg} / \mathrm{L}$ at $30^{\text {th }} \mathrm{min} \mathrm{ET}$, the corresponding aluminum concentration increased to $0.3 \mathrm{mg} / \mathrm{L}$ at 45 min ET exceeding the desirable BIS drinking water standards of $0.03 \mathrm{mg} / \mathrm{L}$ indicating the presence of soluble $\mathrm{Al}(\mathrm{OH})^{4-}$ formed at $\sim \mathrm{pH}$ 8.Contrastingly, iron concentration remained constant (dashed line in Fig. 3a) throughout the ET showing no evidence of iron in the bulk solution.

After the completion of electrolysis, the temperature of the bulk solution $\left(\mathrm{T}_{0}: 22^{\circ} \mathrm{C}\right)$ showed an increase by $3.50 \mathrm{C}$ because of various redox and displacement reactions that occur within the ECR. The flocs formed during the ECC process is a jel like matrix.It was concluded that use of 4 aluminum electrodes was effective in fluoride removal with a marginal contribution to the removal of arsenite.

\section{Effect of using 4iron electrodes (4Fe)}

In another set of experiments, batch ECC was carried out using $4 \mathrm{Fe}$ electrodes with 40 $\mathrm{m}^{2} / \mathrm{m}^{3} \mathrm{SA} / \mathrm{V} . \mathrm{Fe}_{1}-\mathrm{Fe}_{2}-\mathrm{Fe}_{3}-\mathrm{Fe}_{4}$ represents four iron electrode positions in the ECR with $\mathrm{Fe}_{1}$ connected to the positive terminal and Fe4 connected to the negative terminal of the DC power supply unit (Fig. 2b). The other operating parameters andinitial values remained unchanged except for the backgroundiron and aluminum concentration of $0.061 \mathrm{mg} / \mathrm{L}$ and $0 \mathrm{mg} / \mathrm{L}$ respectively.

From the plot (Fig. 3(b), itis observed that a very small decrease in the fluoride removal from
$12 \mathrm{mg} / \mathrm{L}$ to $11.83 \mathrm{mg} / \mathrm{L}$ is observed, while arsenite concentration decreased from $1.6 \mathrm{mg} / \mathrm{L}$ to $0.081 \mathrm{mg} /$ Lat 45 min ET. During the process, the physical color of water changed from colorless to rust yellow within first 5 min because of the in-situ generation of $\mathrm{Fe}^{2+}$ metal ions at the face of anode, beginning with the reactions shown in equations (5) and (6):

$$
\begin{aligned}
& \mathrm{Fe} \rightarrow \mathrm{Fe}^{2+}+2_{\mathrm{e}}^{-} \\
& \mathrm{Fe}^{2+}+2_{\mathrm{e}}^{-} \rightarrow \mathrm{Fe}^{3+}+3_{\mathrm{e}}^{-}
\end{aligned}
$$

Continuing with the reactions in equation (5) and (6), the bulk solution color turns pale yellow ascribed to the formation of $\mathrm{Fe}(\mathrm{OH})_{2}$; these species are soluble and therefore floc formation in the bulk solution wasn't possible. As the ECC treatment progressed, the $\mathrm{pH}$ of the solution changed from acidic to alkaline resulting in color change of the bulk solution from yellow to green and then to blue. Ferric ions reacts with $\mathrm{OH}^{-}$ions forming ferric hydroxide by the reaction (7).

$\mathrm{Fe}^{3+}+3 \mathrm{OH}-\rightarrow \mathrm{Fe}(\mathrm{OH})_{3}$

Formation of $\mathrm{Fe}(\mathrm{OH})_{3}$ leads to red brown colloidal solution. Arsenate co-precipitates with $\mathrm{Fe}(\mathrm{OH})_{3}$ and thus, arsenate gets removed from the bulk solution and the equation (8) justifies this statement:

$$
\mathrm{Fe}(\mathrm{OH})^{3+} \mathrm{AsO}_{4}{ }^{3-} \rightarrow \mathrm{Fe}(\mathrm{OH})_{3}{ }^{*} \mathrm{AsO}_{4}{ }^{3-}
$$

As a result of the reaction in equation (8), the $\mathrm{pH}$ of the bulk solution increased from 8.83 to 9.45. No changes in the bulk solution temperature were observed during the first 15 min after which the temperature increased by $1^{\circ} \mathrm{C}$ at $45 \mathrm{~min} \mathrm{ET}$; it is inferred that while using iron electrodes, the reaction occurring in the cell is less exothermic than when using aluminum electrodes. The residual iron concentration in the treated water at $45 \mathrm{~min}$ ET was $0.066 \mathrm{mg} / \mathrm{L}$ which was well within the prescribed drinking water quality standards as per BIS - 10500 1993 of India and WHO.

\section{Effect of using three aluminum electrodes and one ironelectrode (3Al and 1Fe)}

Batch ECC experiments was carried out by placing aluminum plates in $1^{\text {st }}, 2^{\text {nd }}$ and $4^{\text {th }}$ position and iron electrode placed in the $3^{\text {rd }}$ position in the ECR (Fig. 2c). $\mathrm{Al}_{1}-\mathrm{Al}_{2}-\mathrm{Fe}_{3}-\mathrm{Al}_{4}$ represents $3 \mathrm{Al}$ 
electrodes and $1 \mathrm{Fe}$ electrode. $\mathrm{Al}_{1}$ is connected to the positive terminal, $\mathrm{Fe}^{3}$ is placed in the $3^{\text {rd }}$ position and $\mathrm{Al}_{4}$ is connected to the negative terminal of the DC power supply unit; other operating conditions being the same. The background $\mathrm{Fe}$ and $\mathrm{Al}$ concentration before ECC was $0.061 \mathrm{mg} / \mathrm{L}$ and $0 \mathrm{mg} / \mathrm{L}$ respectively.

From Fig. 3(c) simultaneous improvements in the reduction of both $\mathrm{F}$ - and $\mathrm{As}$ (III) was observed at $45 \mathrm{~min}$ ET compared to the previous two electrode arrangements. During the treatment process, the $\mathrm{pH}$ of the bulk solution reduced from 7.79 to 7.58 with a noticeable color change from colorless to pale yellow within 5 min of ET because of $\mathrm{Fe}^{3+}$ ions and then again changed to green color by 15 min ET because of $\mathrm{Fe}^{2+}$ and $\mathrm{Fe}(\mathrm{OH})_{2}$ ions. The quantity of $\mathrm{Al}$ ions $\mathrm{Al}^{3+}$ generated in the beginning of electrolysis is limited and not sufficient enough to precipitate all F- from water; the removal of As(III) ions was comparatively quicker; however, the concentration of fluoride and arsenite at $45^{\text {th }}$ min ET was above the stipulated standards.

The residual $\mathrm{Al}$ and $\mathrm{Fe}$ concentration in solution were also measured during ECC, it was observed that Fe electrode dissolution was more quickly than the Alelectrodes which provides cross evidence for an increase in Fe concentration from $0.074 \mathrm{mg} / \mathrm{L}$ to $0.451 \mathrm{mg} / \mathrm{L}$ in the bulk solution. At $45^{\text {th }}$ min $E T$, the residual $\mathrm{Al}$ concentration in water was 0 $\mathrm{mg} / \mathrm{L}$ where as the Fe concentration was $0.45 \mathrm{mg} / \mathrm{L}$ little over the limit of $0.3 \mathrm{mg} / \mathrm{L}$. This situation probably demands an additional ET to reach a matured state, where Fe concentration from the solution slowly migrate into the floc matrix and finally into the dry sludge keeping the water free of metal residues.

\section{Effect of using three ironelectrodes and one aluminum electrode (3Fe and $1 \mathrm{Al}$ )}

Iron electrodes were placed parallel in the $1^{\text {st }}, 2^{\text {nd }}$ and $4^{\text {th }}$ position while one aluminum electrode placed in the $3^{\text {rd }}$ position in the ECR in bipolar arrangement; with other operating conditions remaining the same (see sub-caption of Fig: 4.2(d)). The background $\mathrm{Fe}$ and the $\mathrm{Al}$ concentration before ECC was $0.061 \mathrm{mg} / \mathrm{L}$ and $0 \mathrm{mg} / \mathrm{L}$ respectively. Fe electrode in position 1 behaves as an anode while Fe electrode in position 2 behaves both as an anode as well as cathode showing bipolar behavior. Similarly, the $\mathrm{Al}$ electrode in position 3 behaves both as a cathode as well as anode, while the iron electrode in the $4^{\text {th }}$ place $\left(\mathrm{Fe}_{1}-\mathrm{Fe}_{2}-\mathrm{Al}_{3}-\mathrm{Fe}_{4}\right)$ behaves only as a cathode as seen in Fig. 2(d). Electrodes in positions 2 and 3 show hybrid behavior for releasing the respective metal ions into the bulk solution. In the first 5 min of electrolysis, the bulk solution color changes from colorless to rust brown - light green and then to turbid white. The green and yellow mixed color is ascribed to the release of $\mathrm{Fe}^{2+}$ and $\mathrm{Fe}^{3+}$ ions generated during the EC process by anodic oxidation. $\mathrm{Fe}^{2+}$ is the common ion generated in-situ with relatively high solubility in acidic or neutral conditions which easily gets oxidized into $\mathrm{Fe}^{3+}$ using dissolved oxygen in water. The change in color occurs from colorless to rust brown at 5 min ET (pH: 7.99-7.70); rust brown to light green between 5 and $15 \mathrm{~min}$ with $\mathrm{pH}$ : $7.70-7.74$ and finally the solution turns turbid white from light green between 15 and $45 \mathrm{~min}$ $(\mathrm{pH}: 7.76$ - 7.78). This sequential change in color ofthe bulk solution at the end of $45 \mathrm{~min}$ is accompanied with a small decrease in the $\mathrm{pH}$ value of the bulk solutionas reasoned out by the reactions illustrated in the equations 9-11. These reactions simultaneously occurin the vicinity of the active face of the aluminum electrode makingthe solution turbid white as anevidence of $\mathrm{Al}(\mathrm{OH})_{2}$ flocformation and also the formation of $\mathrm{FeCl}_{2}$. The decrease in $\mathrm{pH}$ is because of the liberation of $\mathrm{H}^{+}$ions into the bulk solution.

$$
\begin{aligned}
& \mathrm{Al}^{3+}+\mathrm{H}_{2} \mathrm{O} \rightarrow \mathrm{Al}(\mathrm{OH})^{2+}+\mathrm{H}^{+} \\
& \mathrm{Al}(\mathrm{OH})^{2+}+\mathrm{H}_{2} \mathrm{O} \rightarrow \mathrm{Al}(\mathrm{OH})_{2}^{+}+\mathrm{H}^{+} \\
& \mathrm{Al}(\mathrm{OH})_{2}{ }^{+}+\mathrm{H}_{2} \mathrm{O} \rightarrow \mathrm{Al}(\mathrm{OH})_{3}{ }^{+} \mathrm{H}^{+}
\end{aligned}
$$

It may be observed from Fig. 3(d), as the operating time increases from 0 to $15 \mathrm{~min}$ arsenite and fluoride concentration reduces from 1.6 to 0.072 $\mathrm{mg} / \mathrm{L}$ and 12 to $2.54 \mathrm{mg} / \mathrm{L}$ respectively. It was noticed at $45 \mathrm{~min} \mathrm{ET}$, the concentration of arsenite was 0.042 $\mathrm{mg} / \mathrm{L}$ and fluoridevalue of $0 \mathrm{mg} / \mathrm{L}$.

The retrieved samples were also analyzed for any left overs of residual $\mathrm{Al}$ and $\mathrm{Fe}$ in the solution. The liberation of Fe ions increased from $0.073 \mathrm{mg} / \mathrm{L}$ to $0.279 \mathrm{mg} / \mathrm{L}$ from 0 - $10 \mathrm{~min}$ ET and later the concentration of $\mathrm{Fe}$ ions in the bulk solution showed a constant value of $0.1 \mathrm{mg} / \mathrm{Lup}$ to $45 \mathrm{mins}$, with values well within the BIS drinking water quality standards. With only oneAl electrode in the $3^{\text {rd }}$ position, Al dissolution was meagre and therefore the concentration in the solution was $0 \mathrm{mg} / \mathrm{Lin}$ all the 
sample withdrawal analyzed reflecting the complete utilization of liberated active aluminum ions in the formation of aluminum hydroxides. The liberated Al ions quickly precipitatein floc formation causing fluoride removal.

Conceptually, a complete EC treatment involves three stages - destabilization, aggregation and maturation. The first stage is usually very short- few seconds to minutes involving charge neutralization, the second stage is relatively long which take more time. The last stage takes few minutes to mature where 'sweeps flocculation' occurs. The $\mathrm{Fe}_{1}-\mathrm{Fe}_{2}-\mathrm{Al}_{3}-\mathrm{Fe}_{4}$ electrode combination showed nearly $100 \%$ fluoridere moval with decrease in F- concentration from $12 \mathrm{mg} / \mathrm{L}$ to $0 \mathrm{mg} / \mathrm{L}$ witha multitude reduction in $\mathrm{As}$ (III) concentration reaching a value of $0.04 \mathrm{mg} / \mathrm{L}$ in $30-45 \mathrm{~min}$ from its initial concentrations of $1.6 \mathrm{mg} / \mathrm{L}$. The residual $\mathrm{Al}$ and $\mathrm{Fe}$ concentration in the treated water were $<0.03 \mathrm{mg} / \mathrm{L}$ and $0.3 \mathrm{mg} / \mathrm{L}$ respectively by the end of $45 \mathrm{~min}$ of electrolysis which is well within the stipulated BIS and WHO standards for drinking water, when compared with other electrodes combinations described earlier. An improved performance was observed while using both $\mathrm{Al}$ and $\mathrm{Fe}$ electrodes in a single reactor because of the simultaneous formation of both $\mathrm{Al}$ and Fe hydroxides which complement each other in removing both fluoride and arsenite from water.
Al dissolution tends to reduce the $\mathrm{pH}$ of the water, while iron increases the $\mathrm{pH}$ of water. The combined effect is that both arsenite and fluoride get removed as explained in the reactions (12)and (13).

$$
\begin{aligned}
& \mathrm{Al}(\mathrm{OH})_{3(\mathrm{~s})}+\mathrm{AsO}_{3}{ }^{4-}{ }_{(\mathrm{aq})} \rightarrow\left(\mathrm{Al}(\mathrm{OH})_{3}{ }^{*} \mathrm{AsO}_{3}{ }^{4-}\right)_{(\mathrm{s})} \\
& \mathrm{Fe}(\mathrm{OH})_{3}+\mathrm{AsO}_{4}{ }^{3-} \rightarrow \mathrm{Fe}(\mathrm{OH})_{3}{ }^{*} \mathrm{AsO}_{4}{ }^{3-}
\end{aligned}
$$

The $\mathrm{Al}(\mathrm{OH})_{2}$ flocs formed during electrolysis binds the arsenate present in the water by the mechanism of charged adsorption and the arsenite electro-removal process is by ferric flocs produced by the of all the electrode combinations in different positions in the $\mathrm{ECR}$, the $\mathrm{Fe}_{1}-\mathrm{Fe}_{2}-\mathrm{Al}_{3}-\mathrm{Fe}_{4}$ combination proved an ideal electrode arrangement in the reactor to achieve simultaneous removal of $\mathrm{F}$ - and As(III) from groundwater.

\section{Effect of $\mathrm{Al}$ and Feelectrode placing positions on water quality and production of secondary contaminants in treated water after ECT}

ECC after 45 min ET for all the electrode combinations, the treated water was checked for the presence of secondary contaminants and compared with the BIS-10500 for drinking water. The water quality parameters analyzed for various combinations are shownin Table 4 for various physico-chemical parametersbefore and after the ECC to observe thechanges in the treated water quality.

\begin{tabular}{|c|c|c|c|c|c|c|c|c|}
\hline \multirow[t]{2}{*}{$\begin{array}{l}\text { Sl. } \\
\text { No. }\end{array}$} & \multirow[t]{2}{*}{$\begin{array}{l}\text { Water Quality } \\
\text { Parameter }\end{array}$} & \multirow[t]{2}{*}{ Unit } & \multirow[t]{2}{*}{$\begin{array}{l}\text { BIS-10500,1993 } \\
\text { (Desirable limit) }\end{array}$} & \multirow{2}{*}{$\begin{array}{c}\text { Parameter value } \\
\text { before EC }\end{array}$} & \multicolumn{4}{|c|}{$\begin{array}{l}\text { After } 45 \mathrm{~min} \text { of ECC for operating } \\
\text { Cconditions: } 16 \mathrm{~V} ; \mathrm{As}(\mathrm{III})_{0}: 1.6 \mathrm{mg} / \mathrm{L} ; \mathrm{F}_{0}-: 12 \mathrm{mg} / \mathrm{L}\end{array}$} \\
\hline & & & & & $\mathrm{Al}_{1}-\mathrm{Al}_{2}-\mathrm{Al}_{3}-\mathrm{Al}_{4}$ & $\mathrm{Fe}_{1}-\mathrm{Fe}_{2}-\mathrm{Fe}_{3}-\mathrm{Fe}_{4}$ & $\mathrm{Al}_{1}-\mathrm{Al}_{2}-\mathrm{Fe}_{3}-\mathrm{Al}_{4}$ & $\mathrm{Fe}_{1}-\mathrm{Fe}_{2}-\mathrm{Al}_{3}-\mathrm{Fe}_{4}$ \\
\hline 1 & $\mathrm{pH}$ & - & $6.5-8.5$ & $7.52-7.73$ & 8.1 & 9.45 & 7.58 & 7.76 \\
\hline 2 & Conductivity & $\mu \mathrm{S} / \mathrm{cm}$ & 300 & $807-1075$ & 637 & 703 & 644 & 810 \\
\hline 3 & Turbidity & NTU & 5 & $0.29-1$ & 1.2 & 1.4 & 4.5 & 1.2 \\
\hline 4 & $\begin{array}{l}\text { Total Alkalinity } \\
\text { as } \mathrm{CaCO}_{3}\end{array}$ & $\mathrm{mg} / \mathrm{L}$ & 300 & $360-377$ & 176 & 284 & 204 & 240 \\
\hline 5 & Chloride & $\mathrm{mg} / \mathrm{L}$ & 250 & $70-91$ & 72 & 76 & 72 & 72 \\
\hline 6 & $\begin{array}{l}\text { Total Hardness } \\
\text { as } \mathrm{CaCO}_{3}\end{array}$ & $\mathrm{mg} / \mathrm{L}$ & 300 & $352-463$ & 148 & 216 & 140 & 176 \\
\hline 7 & Calcium & $\mathrm{mg} / \mathrm{L}$ & 75 & $140-160$ & 72 & 96 & 88 & 88 \\
\hline 8 & Magnesium & $\mathrm{mg} / \mathrm{L}$ & 30 & $212-253$ & 76 & 120 & 52 & 88 \\
\hline 9 & Iron & $\mathrm{mg} / \mathrm{L}$ & 0.3 & $0.01-0.03$ & 0.061 & 0.066 & 0.451 & 0.17 \\
\hline 10 & Aluminum & $\mathrm{mg} / \mathrm{L}$ & 0.03 & 0 & 0.392 & 0 & 0 & 0 \\
\hline 11 & Fluoride & $\mathrm{mg} / \mathrm{L}$ & $1-1.5$ & 12 & 0.75 & 11.83 & 4.12 & 0 \\
\hline 12 & Arsenic & $\mathrm{mg} / \mathrm{L}$ & 0.01 & 1.6 & 0 & 0.872 & 0.092 & 0.042 \\
\hline
\end{tabular}

Table 4: Water constituents before and after the ECC treatment process

$\mathrm{pH}$ of the ECC treated water for all the four different electrode combinations increased from its initial $\mathrm{pH}$ as a result ofOH- at the cathode face, because of the buffering character of $\mathrm{Al}(\mathrm{III})$ species especially in this $\mathrm{pH}$ region. From Table 4, it may be seen that for $\mathrm{Al}_{1}-\mathrm{Al}_{2}-\mathrm{Al}_{3}-\mathrm{Al}_{0}, \mathrm{Al}_{1}-\mathrm{Al}_{2}-\mathrm{Fe}_{3}-\mathrm{Al}_{4}$ 
and $\mathrm{Fe}_{1}-\mathrm{Fe}_{2}-\mathrm{Al}_{3}-\mathrm{Fe}_{4}$ at the end of $45 \mathrm{~min} \mathrm{ET}$, the $\mathrm{pH}$ value reached $8.1,7.58$ and 7.76 ; the values were well within the BIS-10500 desirable limit. When using all 4 iron electrodes $\left(\mathrm{Fe}_{1}-\mathrm{Fe}_{2}-\mathrm{Fe}_{3}-\mathrm{Fe}_{4}\right)$, the $\mathrm{pH}$ of treated water was alkaline $(\mathrm{pH}: 9.45)$ exceeding the $\mathrm{pH}$ limit of $6.5-8.5$ with an obvious inference that iron electrodes generate more $\mathrm{OH}$ - ions in the presence of sufficient alkalinity. The conductivity of the ECC treated water decreased from its initial value ascribed to the removal of various anions and cations by various redox and chemical coagulation reactions that occur during the electrolysis process. A major portion of the conductivity value is utilized in floc formation. The decrease in conductivity indicates ion pairing or multiple-ion association between solvated species and opposite charges ${ }^{19}$. It may be observed from Table 4, conductivity value after treatment for $\mathrm{Al}_{1}-\mathrm{Al}_{2}-\mathrm{Al}_{3}-\mathrm{Al}_{4}, \mathrm{Fe}_{1}-\mathrm{Fe}_{2}-\mathrm{Fe}_{3}-\mathrm{Fe}_{4}, \mathrm{Al}_{1}-\mathrm{Al}_{2}-\mathrm{Fe}_{3}-\mathrm{Al}_{4}$ and $\mathrm{Fe}_{1}-\mathrm{Fe}_{2}-\mathrm{Al}_{3}-\mathrm{Fe}_{4}$ were 637, 703, 644 and $810 \mu \mathrm{S} / \mathrm{cm}$ respectively from its initial values of $807-1075 \mu \mathrm{S} /$ $\mathrm{cm}$. The turbidity values after $\mathrm{ECC}$ with $\mathrm{Al}_{1}-\mathrm{Al}_{2}-\mathrm{Al}_{3}-\mathrm{Al}_{4}$, $\mathrm{Fe}_{1}-\mathrm{Fe}_{2}-\mathrm{Fe}_{3}-\mathrm{Fe}_{4}, \mathrm{Al}_{1}-\mathrm{Al}_{2}-\mathrm{Fe}_{3}-\mathrm{Al}_{4}$ and $\mathrm{Fe}_{1}-\mathrm{Fe}_{2}-\mathrm{Al}_{3}-\mathrm{Fe}_{4}$ electrode combinations were 1.2, 1.4, 4.5 and 1.2 NTU respectivelywhich is greater than the initial values. The increase in turbidity is because of micro gas bubbles which quickly buoy up along with the $\mathrm{M}^{+}$metal ions from the solution. Sometimes, the dissolved $\mathrm{Al}$ gets polymerized $\operatorname{as} \mathrm{Al}(\mathrm{OH})_{2}$ there by increasing the turbidity of water.

Inthe post ECC supernatant, the total alkalinity (as $\mathrm{CaCO}_{3}$ ) value decreased by 21.11$53.31 \%$ for all the electrode combinations to safe levels from its initial concentration of $360-377 \mathrm{mg} / \mathrm{L}$. The decrease in total alkalinity after ECC is because of the consumption of alkalinity salts such as carbonates and bicarbonates during the ECC process. The reactions inequations (14), (15) and (16) releases $\mathrm{CO}_{2}$ gas leading to slight increase in the $\mathrm{pH}$ of the bulk solution leading to alkalinity consumption.

$$
\begin{aligned}
& \mathrm{H}^{+}+\mathrm{HCO}_{3}^{-} \rightarrow \mathrm{H}_{2} \mathrm{O}+\mathrm{CO}_{2} \\
& \mathrm{H}^{+}+\mathrm{CO}_{3}^{-} \rightarrow \mathrm{H}_{2} \mathrm{O}+\mathrm{CO}_{2} \uparrow \\
& \mathrm{H}^{+}+\mathrm{OH}-\rightarrow \mathrm{H}_{2} \mathrm{O}
\end{aligned}
$$

Also, $\mathrm{Mg}$ ions present in the bulk solution reacts with carbonate ions forming magnesium carbonate (Equation 17) and hence forth both magnesium ions and alkalinity reduce with ET.

$$
\mathrm{Mg}^{2+}+\mathrm{CO}_{3}^{2-} \rightarrow \mathrm{MgCO}_{3} \downarrow
$$

In simple terms, a sufficient background alkalinity in the water become very useful in floc formation; else, in its absence, the water becomes turbid and toxic with large releases of $\mathrm{M}^{+}$and non - participation of these $\mathrm{M}^{+}$ions not picking up the negatively charged contaminants/ pollutants.

Presence of sufficient useful salts $(\mathrm{Cl}-, \mathrm{Na}, \mathrm{Ca}$ and $\mathrm{Mg})$ in water reduces the treatment time and promotes floc formation in the presence of total alkalinity. Chloride values decreased byan average of $8.75 \%$ for all the electrode combinations after ECC treatment. As reported by ${ }^{20}$ the oxidation process converts, chloride ions into chlorine gas causing a reduction in chloride concentration in the ECC treated supernatant. Thechlorine gas so released is used as an oxidant to convert ferrous iron to insoluble ferric iron. The presence of ferrous ions and chloride ion in the effluent may also tend to form amorphous $\mathrm{Fe}(\mathrm{OH})_{3}$ as reported by ${ }^{21}$ and as a result, the concentration of the chloride ions is reduced from its initial concentration after ECC by the reactions (18), (19) and (20).

$$
\begin{aligned}
& 2 \mathrm{Cl}_{-}{ }_{(\mathrm{aq})} \rightarrow \mathrm{Cl}_{2(\mathrm{~g})}+2 \mathrm{e}^{-} \\
& \mathrm{Fe}^{2+}+2 \mathrm{Cl}-\rightarrow \mathrm{FeCl}_{2} \\
& \mathrm{FeCl}_{2}+3 \mathrm{OH}-\rightarrow \mathrm{Fe}(\mathrm{OH})_{3}+2 \mathrm{Cl}^{-}
\end{aligned}
$$

The total hardness value after ECC for $\mathrm{Al}_{1}-\mathrm{Al}_{2}-\mathrm{Al}_{3}-\mathrm{Al}_{4}, \mathrm{Fe}_{1}-\mathrm{Fe}_{2}-\mathrm{Fe}_{3}-\mathrm{Fe}_{4}, \mathrm{Al}_{1}-\mathrm{Al}_{2}-\mathrm{Fe}_{3}-\mathrm{Al}_{4}$ and $\mathrm{Fe}_{1}-\mathrm{Fe}_{2}-\mathrm{Al}_{3}-\mathrm{Fe}_{4}$ electrode combinations were 148 , 216,140 and $176 \mathrm{mg} / \mathrm{L}$ respectively from its initial value of $352-463 \mathrm{mg} / \mathrm{L}$. Precipitation of the calcium and magnesium ions to $\mathrm{Ca}(\mathrm{OH})_{2}$ and $\mathrm{Mg}(\mathrm{OH})_{2}$ into the gel matrix results in the hardness removal as shown in the equations (21) and(22).

$$
\begin{aligned}
& \mathrm{Ca}^{2+}+\mathrm{OH}-\rightarrow \mathrm{Ca}(\mathrm{OH})_{2} \\
& \mathrm{Mg}^{2+}+\mathrm{OH}-\rightarrow \mathrm{Mg}(\mathrm{OH})_{2}
\end{aligned}
$$

Calcium and magnesium ions playsa very important role in adsorption and precipitation of F-ions as shown by the reactions in (23) and (24). These reactions occur near the cathode face of the respective electrode when the water $\mathrm{pH}$ crosses 8. The added benefit is that contamination in hard water (groundwater) is easy toremove compared with waters/waste water that aresoft. In addition to the removal of fluoride and arsenic, the water becomes softer after ECC because Ca \& Mg ions get removed from the solution. 
$\mathrm{Mg}_{(\mathrm{aq})}{ }^{2+}+2 \mathrm{~F}_{-}{ }_{(\mathrm{aq})} \rightarrow \mathrm{MgF}_{2(\mathrm{~s})}$

$\mathrm{Ca}_{(\mathrm{aq})}^{2+}+2 \mathrm{~F}_{-}^{-}{ }_{(\mathrm{aq})} \rightarrow \mathrm{CaF}_{2(\mathrm{~s})}$

For any drinking water treatment process, using $\mathrm{Al}$ and $\mathrm{Fe}$ salts, the residual $\mathrm{Al}$ and $\mathrm{Fe}$ ion concentration in water is an important consideration. The electrochemically treated water samples were checked for the presence of aluminum and ferrous/ ferric ions. It was observed that $\mathrm{Al}$ and ferrous/ferric ions concentration in solution changed for each combination of the electrodes. It maybe observed in Table 4 for $\mathrm{Al}_{1}-\mathrm{Al}_{2}-\mathrm{Al}_{3}-\mathrm{Al}_{4}$ electrode combination, the residual $\mathrm{Al}$ is $0.392 \mathrm{mg} / \mathrm{L}$ which is against the stipulated BIS - 10500 standard of $0.03 \mathrm{mg} / \mathrm{L} \&$ WHO standard of $0.2 \mathrm{mg} / \mathrm{L}$, where as, the residual $\mathrm{Al}$ concentration was $0 \mathrm{mg} / \mathrm{L}$ forFe $\mathrm{F}_{1}-\mathrm{Fe}_{2}-\mathrm{Fe}_{3}-\mathrm{Fe}_{4}, \mathrm{Al}_{1}-\mathrm{Al}_{2}-$ $\mathrm{Fe}_{3}-\mathrm{Al}_{4}$ and $\mathrm{Fe}_{1}-\mathrm{Fe}_{2}-\mathrm{Al}_{3}-\mathrm{Fe}_{4}$ electrode combinations. Residual Fe concentrations for $\mathrm{Al}_{1}-\mathrm{Al}_{2}-\mathrm{Al}_{3}-\mathrm{Al}_{4}, \mathrm{Fe}_{1}$ $\mathrm{Fe}_{2}-\mathrm{Fe}_{3}-\mathrm{Fe}_{4}$ and $\mathrm{Fe}_{1}-\mathrm{Fe}_{2}-\mathrm{Al}_{3}-\mathrm{Fe}_{4}$ were $0.061,0.066$ and $0.17 \mathrm{mg} / \mathrm{L}$ respectively, well within the BIS - 10500 and WHO standards, but for $\mathrm{Al}_{1}-\mathrm{Al}_{2}-\mathrm{Fe}_{3}$ $\mathrm{Al}_{4}$ the residual Fe concentration was $0.451 \mathrm{mg} / \mathrm{L}$, marginally higher than the permissible value of 0.3 $\mathrm{mg} / \mathrm{L}$. Therefore, by considering both water quality and simultaneous arsenite and fluoride removal, the $\mathrm{Fe}_{1}-\mathrm{Fe}_{2}-\mathrm{Al}_{3}-\mathrm{Fe}_{4}$ electrode combination was seen best suitable for pollutant removal.

An important out come is that when using both $\mathrm{Fe}$ and $\mathrm{Al}$ electrode combinations, the ECC treatment doesnot impart any significant Fe and $\mathrm{Al}$ ion residues into water marking the useful potential of ECC without any sort of secondary contamination of treated water

\section{Effect of electrode type and position in the ECR for electrode dissolution (ED), energy consumption, sludge quantity and operating cost (OC)}

Major issuesfor accepting the use of ECC is the electrode consumption (ED), post ECC water quality, sludge generation, operating cost (OC) and energy consumption. Fig. 4(a-e) illustrates the effect of different electrode positions on ET for the removal of excess arsenite and fluoride to meet the prescribed drinking water quality standards. As seen in Fig. 4(a), the $\mathrm{Fe}_{1}-\mathrm{Fe}_{2}-\mathrm{Al}_{3}-\mathrm{Fe}_{4}$ electrode placing position showed electrode dissolution $0.667 \mathrm{Kg} / \mathrm{m}^{3}$ in $45 \mathrm{~min}$ ET. Itmay be observed that with more iron electrodes than Ali.e. for $\mathrm{Fe}_{1}-\mathrm{Fe}_{2}-\mathrm{Fe}_{3}-\mathrm{Fe}_{4}$ and $\mathrm{Fe}_{1}-\mathrm{Fe}_{2}-\mathrm{Al}_{3}-\mathrm{Fe}_{4}$ electrode combinations, the electrode dissolution from the Fe electrode is 0.606 and 0.498
$\mathrm{Kg} / \mathrm{m}^{3}$. While using only $\mathrm{Al}_{1}-\mathrm{Al}_{2}-\mathrm{Al}_{3}-\mathrm{Al}_{4}$ and $\mathrm{Al}_{1}-\mathrm{Al}_{2}-$ $\mathrm{Fe}_{3}-\mathrm{Al}_{4}$ combinations, the amount of Alions liberated is significantly less: 0.303 and $0.214 \mathrm{Kg} / \mathrm{m}^{3}$.

The gross sludge quantity generated for the four different electrode combinations were 0.955 , $0.99,0.915$ and $1.115 \mathrm{Kg} / \mathrm{m}^{3}$ for $\mathrm{Al}_{1}-\mathrm{Al}_{2}-\mathrm{Al}_{3}-\mathrm{Al}_{4} ; \mathrm{Fe}_{1}-$ $\mathrm{Fe}_{2}-\mathrm{Fe}_{3}-\mathrm{Fe}_{4} ; \mathrm{Al}_{1}-\mathrm{Al}_{2}-\mathrm{Fe}_{3}-\mathrm{Al}_{4}$ and $\mathrm{Fe}_{1}-\mathrm{Fe}_{2}-\mathrm{Al}_{3}-\mathrm{Fe}_{4}$ combination respectively and the same is plotted in Fig. 4(b). The quantity of sludge generation reflects floc formation by active electro-coagulating agents; using the $\mathrm{Fe}_{1}-\mathrm{Fe}_{2}-\mathrm{Al}_{3}-\mathrm{Fe}_{4}$ combination both $\mathrm{Fe}(\mathrm{OH})_{2}$ and $\mathrm{Al}(\mathrm{OH})_{3}$ formation occurs as reported by ${ }^{22}$ explained by the equation(25).

$$
\mathrm{Fe}_{(\mathrm{s})}+\mathrm{Al}(\mathrm{s})+2 \mathrm{H}_{2} \mathrm{O} \rightarrow \mathrm{Fe}(\mathrm{OH})_{2}+\mathrm{Al}(\mathrm{OH})_{3}+\mathrm{H}_{2(\mathrm{~g})}
$$

\section{Operating Cost (OC)}

The success of any water/wastewater treatment option is its 'Operating cost'. Inthe ECC treatment process, the $\mathrm{OC}$ includes material electrodes cost, utility cost (electrical energy), labor, maintenance and other fixed costs ${ }^{23}$. The major components like - cost of energy, electrode material and chemicals (Equation 26) for the treated water were taken into account to arrive at the 'operating cost'in Indian Rupee(INR) for each cubic meter of water treated.

Operating Cost $=a \mathrm{C}_{\text {energy }}+\mathrm{bC}_{\text {electrode }}+\mathrm{CC}_{\text {chemical }}$

Where, $\mathrm{C}$ energy is the energy consumption in $\mathrm{kWh}$ per $\mathrm{m}^{3}$ of water treated using equation (27).

$$
\mathrm{C}_{\text {energy }}=C_{\text {energy }}=\frac{\text { V.I.t }}{\text { Treated Volume }(L)}
$$

$\mathrm{C}_{\text {electrodeis }}$ the electrode consumption in $\mathrm{kg}$ per $\mathrm{m}^{3}$ of water treated that is calculated as shown in equation (28).

$$
\mathrm{C}_{\text {electrode }}=C_{\text {electrode }}=\frac{\text { I.t.M } \cdot M_{w}}{Z \cdot F \cdot V}
$$

Where, $\mathrm{I}$ is the current $(\mathrm{A})$, $\mathrm{t}$ is the electrolysis time in seconds, $M$ is the molecular mass of iron $(0.05585 \mathrm{~kg} / \mathrm{mol})$ and aluminum $(0.02968 \mathrm{k} / \mathrm{mol}), Z$ is the number of electrons transferred for iron $\left(Z_{\mathrm{Fe}}=2\right)$ and aluminum $\left(Z_{\mathrm{Al}}=3\right), \mathrm{F}$ is the Faraday's constant $(96485 \mathrm{C} / \mathrm{mol})$ and $V$ is the volume of effluent treated in $\mathrm{m}^{3} . \mathrm{C}_{\text {chemicals }}$ is the chemical consumption in $\mathrm{kg}$ per $\mathrm{m}^{3}$ of water treated. The unit prices $a, b$ and $c$ for the Indian market are as follows: ' $a$ ' is the electrical 
energy prices of 0.0065 US $\$$ / KWh; 'b' is electrode material price as 0.3 US $\$ / \mathrm{kg}$ averaged for aluminum and iron respectively, 'c' is price of chemicals which is zero Rs./kg, as no chemical are used as additives in the treatment process.

The OC for different electrode combinations were calculated using equation (26) for the simultane ous removal of arsenic and fluoride from groundwater. The results in Fig. 4(c) shows the lowest operating costs for $\mathrm{Al}_{1}-\mathrm{Al}_{2}-\mathrm{Al}_{3}-\mathrm{Al}_{4} ; \mathrm{Fe}_{1}-\mathrm{Fe}_{2}-\mathrm{Fe}_{3}-\mathrm{Fe}_{4} ; \mathrm{Al}_{1}-\mathrm{Al}_{2}-\mathrm{Fe}_{3}-$ $\mathrm{Al}_{4}$ and $\mathrm{Fe}_{1}-\mathrm{Fe}_{2}-\mathrm{Al}_{3}-\mathrm{Fe}_{4}$ as Rs. 3.44, 1.55, 2.07 and $2.90 \mathrm{Rs} . / \mathrm{m}^{3}$ for $45 \mathrm{~min}$ ET respectively. An electrode combination of $\mathrm{Fe}_{1}-\mathrm{Fe}_{2}-\mathrm{Al}_{3}-\mathrm{Fe}_{4}\left(\mathrm{SA} / \mathrm{V} 40 \mathrm{~m}^{2} / \mathrm{m}^{3}\right)$ for $16 \mathrm{~V}$ and $0.67 \mathrm{~A}$ for $45 \mathrm{~min}$ of ET was consideredas the best electrode arrangement giving a small operating cost of $2.90 \mathrm{Rs} . / \mathrm{m}^{3}$ for simultaneous removal of fluoride and arsenic.

Electrical energy consumption is calculated for the a fore said different electrode arrangements for both arsenite and fluoride removal simultaneously using the equation(29) which was also used by ${ }^{24}$ for study carried out fortreatment of paper mill effluent in batch stirred electrochemical tank reactor.

Energy Consumption $\left(\mathrm{kWh} /{ }_{\mathrm{m} 3}\right)=\frac{\text { V.I.t }}{\text { Treated Volume }(L)}$

Where, $\mathrm{V}$ is the applied cell voltage in volts, $I$ is the current in ampere $(A)$ and $t$ is the treatment time in hours. As observed from Fig. 4(d) and Fig. 4(e), the energy consumption and \% arsenite and fluoride removal for four different electrode combinations were 1.83, 1.98, 2.04 and $2.01 \mathrm{KWh} /$ $\mathrm{m}^{3}$ for simultaneous removal of As(III) as 33\%, 93\%, $92 \%$ and $96.5 \%$ and $\mathrm{F}$ - of $93 \%, 1.4 \%, 65 \%$ and $100 \%$ respectively.

Therefore, it was concluded that with one single ECC treatment for an electrode combination $\mathrm{Fe}_{1}-\mathrm{Fe}_{2}-\mathrm{Al}_{3}-\mathrm{Fe}_{4}\left(\mathrm{SA} / \mathrm{V}: 40 \mathrm{~m}^{2} / \mathrm{m}^{3}\right)$ in a bipolar arrangement providing simultaneous removal of both $\mathrm{As}$ (III) and $\mathrm{F}$ - at a meagre cost was achieved at $45 \mathrm{~min}$ ET and agood potable quality water. The water quality can further be improved by providing a small filtration unit down-line the ECC unit to remove small turbid particles if any.
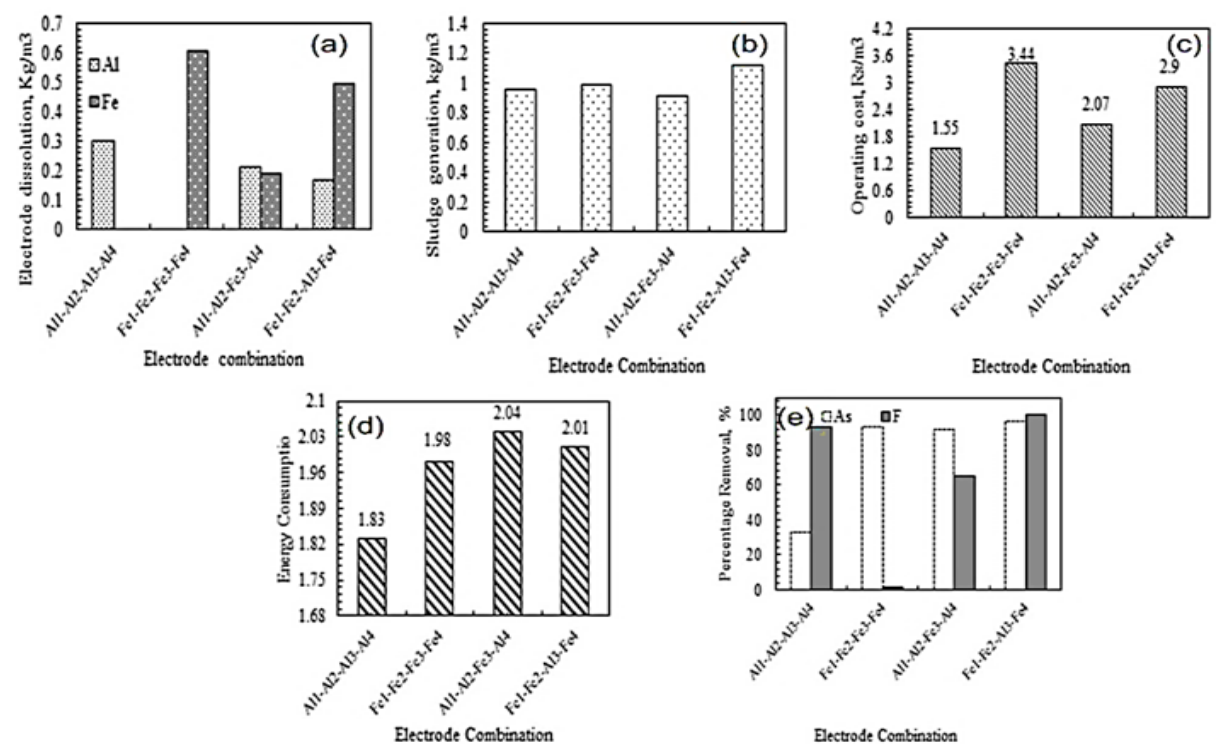

Fig. 4. Effect of different electrode placing positions inside the ECC Reactor on (a) Electrode Dissolution (b) Sludge Generation (c) Operating cost (d) Energy Consumption and (e) Percentage simultaneous removal of arsenite and fluoride Operating conditions Bipolar arrangement; No. of plate electrodes: 4; As (III)0 : 1.6 mg/L; F0 -: 12 mg/L; Al3+: 0 mg/L; Fe0: $0.061 \mathrm{mg} / \mathrm{L}$; Interelectrode spacing: $5 \mathrm{~mm}$; Applied cell voltage: $16 \mathrm{~V}$; SA/V ratio: $40 \mathrm{~m} 2 / \mathrm{m} 3$ and Electrolysis time: $45 \mathrm{minutes}$

\section{CONCLUSION}

ECC studies were carried out for simultaneous removal of both fluoride and arsenic from groundwater using $\mathrm{Al}$ and $\mathrm{Fe}$ plate electrodes for its placing position in the ECR. Preceded by a large set of experiments on electrode combinations using $\mathrm{Fe}$ and $\mathrm{Al}, 4$ set of experiments with selected electrode 
combinations: (i) $\mathrm{Al}_{1}-\mathrm{Al}_{2}-\mathrm{Al}_{3}-\mathrm{Al}_{4}$ (ii) $\mathrm{Fe}_{1}-\mathrm{Fe}_{2}-\mathrm{Fe}_{3}-\mathrm{Fe}_{4}$ (iii) $\mathrm{Al}_{1}-\mathrm{Al}_{2}-\mathrm{Fe}_{3}-\mathrm{Al}_{4}$ and (iv) $\mathrm{Fe}_{1}-\mathrm{Fe}_{2}-\mathrm{Al}_{3}-\mathrm{Fe}_{4}$ were identified for detailed studies and carried out for an operating condition withbipolar arrangement, Electrodeno: 4, SA/V ratio: $40 \mathrm{~m}^{2} / \mathrm{m}^{3}$, $\mathrm{pH}: 7.99, \mathrm{As}(\mathrm{III})_{0}: 1.6 \mathrm{mg} / \mathrm{L}, \mathrm{F}_{0}-$ : $12 \mathrm{mg} / \mathrm{L}, \mathrm{Al}_{0}^{3+}: 0 \mathrm{mg} / \mathrm{L}, \mathrm{Fe}_{0}: 0.061 \mathrm{mg} / \mathrm{L}$, Electrode spacing: $5 \mathrm{~mm}$, cell voltage: $16 \mathrm{~V}$, average current: $0.67 \mathrm{~A}$, and $45 \mathrm{~min}$ ET. The following conclusions weredrawn:

$\mathrm{Fe}_{1}-\mathrm{Fe}_{2}-\mathrm{Al}_{3}-\mathrm{Fe}_{4}$ electrode combination proved most effective and efficient for simultaneous removal of arsenite and fluoride from ground water. The concentration of arsenite and fluoride reduced to $0.04 \mathrm{mg} / \mathrm{L}$ and $0 \mathrm{mg} / \mathrm{L}$ at $30-45 \mathrm{~min}$ ET from its initial concentration of $1.6 \mathrm{mg} / \mathrm{L}$ and $12 \mathrm{mg} / \mathrm{L}$.

Other drinking water quality parameter sanalyzed after ECC treatment were well within the drinking water standards prescribed by both BIS and WHO, with no addition of secondary pollutantsinto water. However, water quality after ECC for electrode combinations like $\mathrm{Al}_{1}-\mathrm{Al}_{2}-\mathrm{Al}_{3}-\mathrm{Al}_{4}, \mathrm{Fe}_{1}-\mathrm{Fe}_{2}-\mathrm{Fe}_{3}-\mathrm{Fe}_{4}$ and $\mathrm{Al}_{1}-\mathrm{Al}_{2}-\mathrm{Fe}_{3}-\mathrm{Al}_{4}$ were unsatisfactory because of inefficient removal of $\mathrm{As}$ (III) and F-and alsoresidual iron and aluminum ions in water werenoticed.

Cost wise economics for $\mathrm{Fe}_{1}-\mathrm{Fe}_{2}-\mathrm{Al}_{3}-\mathrm{Fe}_{4}$ showeda good combination with $0.667 \mathrm{~kg} / \mathrm{m}^{3}$ of electrode dissolution, $1.115 \mathrm{~kg} / \mathrm{m}^{3}$ of dry sludge generation, energy consumption of $2.01 \mathrm{KWh} / \mathrm{m}^{3}$; the overall operating cost being $2.90 \mathrm{Rs} . / \mathrm{m}^{3}$ of water treated. For the operating conditions: bipolar $\mathrm{Fe}_{1}-\mathrm{Fe}_{2}-$ $\mathrm{Al}_{3}-\mathrm{Fe}_{4}$; electrode spacing: $5 \mathrm{~mm} ; \mathrm{pH}_{0}$ : 8.9; $\mathrm{As}(\mathrm{III})_{0}$ : $1.6 \mathrm{mg} / \mathrm{L} ; \mathrm{F}_{0}-: 12 \mathrm{mg} / \mathrm{L} ; \mathrm{Al}^{3+}: 0 \mathrm{mg} / \mathrm{L} ; \mathrm{Fe}_{0}: 0.061 \mathrm{mg} / \mathrm{L}$; inter-electrode spacing: $5 \mathrm{~mm}$; E. no: 4 ; voltage: 16 Volts; average current: $0.66 \mathrm{~A}$; SA/V ratio: $40 \mathrm{~m}^{2 /}$ $\mathrm{m}^{3}$ and an electrolysis time of 45 minutes.

These experimental results dictate then ovelty of ECC removing both arsenite and fluoride simultaneously adsorbed to the co-precipitating with hydrous aluminum oxide and ferric oxide. The ECC process with $\mathrm{Fe}_{1}-\mathrm{Fe}_{2}-\mathrm{Al}_{3}-\mathrm{Fe}_{4}$ configuration signifies a note-worthy substitute/a retrofit for treatment systems that operate separately for As(III) and F- removal, stillretaining the beneficial water minerals in ground water as is.

The electrode placing position plays a very important role inthe ECC treatment process for effective removal of both arsenite and fluoride from groundwater.This approach offsets the use of separate treatment technologies for removal ofboth arsenite and fluoride in one cost effective treatment with reduced capital cost, operation and maintenance costs and low energy foot prints.

\section{ACKNOWLEDGEMENT}

The authors are thankful to Sri Jaya chama rajendra College of Engineering (JSS S\&T University), Mysuru for giving the opportunity to carry out this research work.

\section{REFERENCES}

1. Nollet, L. M., Handbook of Water Analysis, 2ndedn. Ch.1. New York: CRC Press., 2007.

2. Ehrenstein, O. S. V., Mazumder, D.N.G., Yuan, Y.,Samanta, S., Balmes, J., Sil, A., Ghosh, N., Smith, M. H., Haque, R., Purushothaman, R., Lahiri, S., Das, S., and Smith, A. H., American Journal of Epidemiology., 2005, 162, 533-541.

3. Grandjean, P., Olsen, J. H., Jensen, O.M., Juel, K. J., Cancer incidents and mortality in workers exposed to fluoride. National Cancer Institute (Bathesda)., 1992, 84, 1903-1909.

4. World Health Organization.Guidelines for drinking water quality: Remediations., 1993, 1 ( $3^{\text {rd }}$ edition). Geneva: WHO.

5. IS: 10500, Bureau of Indian Standards., 1983.
6. Hering, J. G., Chen, P. Y., Wilkie, J. A., Elimelech, M., Liang, S., J. Am. Water Works Assoc., 1996, 155-167.

7. Li, Y., Zhang, F. S.,Xiu, F.R., Sci. Total Environ., 2009, 407, 5780-5786.

8. Mohan, D and Pittman, C. U., J. Hazard. Mater., 2007, 142, 1-53.

9. Chauhan,V. S.,Dwivedi, P. K., lyengar, L, J. Hazard. Mater., 2007, 139, 103-107.

10. Mjengera, $\mathrm{H}$ and Mkongo, G., Phys. Chem. Earth., 2003, 28, 1097-1104.

11. Kumar, S., Gupta, A., Yadav, J. P., Ind. J. Chem. Techn., 2007, 14, 355-361.

12. Pinon-Miramontes, M., Bautista-Margulis, R. G., Perez-Hernandez, A., Fluoride., 2003, 36, 122-128. 
13. Tahaikt, M., Achary, I., Menkouchi, S. M. A., Amor, Z., Taky, M., Alami, A., Boughriba, A., Hafsi, M.,Elmidaoui, A., Desalination., 2006, 189, 215-220.

14. Arora, M.,Maheshwari, R. C., Jain, S. K., Gupta, A.,Desalination, 2004,170, 105-112.

15. Hu, K and Dickson, J. M., J. Mem. Sci., 2006, 279, 529-538.

16. Baird, R. B., Eaton, A. D., Rice, E.W., APHA, 2017.

17. Pletcher, D. and Walsh, F.C., Chapman and Hall, London, UK., 1990.

18. Moudhen, G., Feki, M., Wery, M.,Ayedi, H., J. Haz. Mat., 2008, 150, 124-135.

19. Hung, H.C., Luke, C., Lu, Y.C., Sep. Purif.
Technol., 2009, 65, 137-146.

20. Bukhari, A. A.,Abuzaid, N. S.,Abdulappa, M. K., Essa, M. H., Int. Fifth Saudi Engineering Conference., 1999, 3, 293-301.

21. Ghosh, D., Solanki, H., Purkait, M. K., J. Haz. Mat., 2008, 155, 135-143.

22. Hernandez, I. L., Diaz, C. B., Morales, G.R., Bilyeu, B., Nunez, F. U., Chem. Eng. J., 2009, 148, 97-105.

23. Donini, J.C., Kan, J., Szynkarczuk, J., Hassan, T.A., Kar, K.L., Can., J. Chem. Eng., 1994, 72, 1007-1012.

24. El-Ashtoukhy E-SZ.,Amin, N.K.,Abdelwahab, O, Chem. Eng. J., 2009, 146, 205-210. 